\title{
PENGARUH TERAPI ASERTIF TERHADAP KECENDERUNGAN PERILAKU BULLYING PADA SISWA SMPN 1 RAJEG KABUPATEN TANGERANG
}

\author{
Ema Hikmah*, Parta Suhanda**
}

\begin{abstract}
Abstrak
Perilaku asertif tidak bisa.dibentuk secara instan, tetapi harus dilatih secara terus menerus melalui role model, baik di rumah oleh orangtua, di sekolah oleh guru dan teman sebaya. Perilaku yang terjadi pada anak, yang sifatnya menyimpang harus di evaluasi agar guru dan orangtua dapat mengatasi sedini mungkin sehingga perilaku tersebut dapat berubah kearah yang lebih baik. Data menyebutkan $84 \%$ anak Indonesia mengalami kekerasan (bullying) baik fisik maupun psikis. Penelitian ini bertujuan untuk mengetahui pengaruh terapi asertif terhadap kecenderungan perilaku bullying. Tempat penelitian adalah di SMPN 1 Rajeg Kabupaten Tangerang periode Juni sampai Nopember 2016. Penelitian ini menggunakan desain penelitian kuasi-eksperimen. Jumlah responden dalam penelitian ini adalah 84 siswa dengan rincian 43 orang kelompok control dan 41 orang kelompok intervensi. Desain kuasieksperimen dalam penelitian menggunakan tipe onegroup design dengan pre dan post test. Analisi bivariat yang digunakan adalah t-test independent. Hasil penelitian pada kelompok intervensi diketahui ada penurunan kecenderungan perilaku bullying yaitu nilai rerata sebelum dilakukan terapi asertif yaitu 45,8 dengan standar deviasi 5,286 dan setelah dilakukan terapi asertif adalah 40,71 dengan standar deviasi 5,098 dengan $p$ value $=0,000 \alpha=0,05$. Hasil yang signifikan pada penelitian ini menunjukan bahwa hal ini bermakna apabila terapi asertif dilakukan maka kecenderungan perilaku bullying akan menurun.
\end{abstract}

Kata kunci : Terapi Asertif, kecenderungan perilaku bulying, Pre-post Study

*,**) Dosen Jurusan Keperawatan Tangerang Poltekkes Kemenkes Banten 


\section{Pendahuluan}

Perilaku bullying akhir-akhir ini menjadi permasalahan yang harus diwaspadai oleh orangtua dan guru, karena data menunjukkan perilaku bullying ini semakin hari semakin meningkat jumlahnya. Keadaan yang mengkhawatirkan perilaku bullying ini sudah dilakukan oleh anak-anak yang usianya masih kecil, mulai dari usia toddler atau ketika anak masih sebagian besar waktunyya berada di rumah. Perilaku bullying dapat bersifat fisik dan psikologis, dari ringan sampai berat. Menurut psikolog Andrew Mellor, bullying adalah pengalaman yang terjadi ketika seseorang merasa teraniaya oleh tindakan orang lain dan ia takut apabila perilaku buruk tersebut akan terjadi lagi sedangkan korban merasa tidak berdaya untuk mencegahnya. Bullying tidak lepas dari adanya kesenjangan power/kekuatan antara korban dan pelaku serta diikuti pola repetisi (pengulangan perilaku). Lebih lanjut, Andrew Mellor menjelaskan bahwa ada beberapa jenis bullying, yakni: (1) bullying fisik, yaitu jenis bullying yang melibatkan kontak fisik antara pelaku dan korban. Perilaku yang termasuk, antara lain: memukul, menendang, meludahi, mendorong, mencekik, melukai menggunakan benda, memaksa korban melakukan aktivitas fisik tertentu, menjambak, merusak benda milik korban, dan lain-lain. Bullying fisik adalah jenis yang paling tampak dan mudah untuk diidentifikasi dibandingkan bullying jenis lainnya; (2) bullying verbal melibatkan bahasa verbal yang bertujuan menyakiti hati seseorang. (3) bullying relasi sosial adalah jenis bullying bertujuan menolak dan memutus relasi sosial korban dengan orang lain, meliputi pelemahan harga diri korban secara sistematis melalui pengabaian, pengucilan atau penghindaran. (4) bullying elektronik merupakan merupakan bentuk perilaku bullying yang dilakukan melalui media elektronik seperti komputer, handphone, internet, website, chatting room, e-mail, SMS, dan lain-lain.

Perilaku Bullying yang terjadi di SMPN 1 Rajeg teridentifikasi pada saat peneliti memberikan kuesioner pada siswa kelas 8. Seluruh Siswa Kelas 8 diberikan Kuesioner yang berisi pertanyaan seputar perilaku Bullying. Dari Kuesioner yang dibagikan diisi oleh 524 siswa. Dari 524 siswa yang pernah mengalami Bullying sejumlah 504 siswa atau 96,2 \%. Siwa yang mendapatkan bullying, sebanyak 412 siswa atau $82 \%$ mendapatkan perlakuan tersebut dari teman sekelas. Perlakuan Bullying yang lain didapatkan dari orangtua, guru dan saudara kandung. 


\section{Metoda Penelitian}

Penelitian ini menggunakan desain kuasi-eksperimen, dengan menggunakan tipe nonequivalent control group design dengan pre dan post test. Intervensi yang diberikan adalah memberikan terapi asertif diberikan pada kelompok perlakuan, sedangkan pada kelompok kontrol tidak. Sampel dalam penelitian ini berjumlah 84 siswa yang terdiri dari 41 siswa kelompok intervensi dan 43 siswa kelompok kontrol. kriteria pemilihan dimasukkan dalam penelitian sampai jumlah subyek penelitian terpenuhi.

Kegiatan penelitian ini meliputi tindakan terapi asertif sebanyak 4 sesi. Analisis data dalam penelitian ini diolah dengan program statistik. Analisis bivariat untuk sampel berpasangan digunakan uji $t$ test dependen dan untuk data yang tidak berpasangan dilakuakan uji t-tes independen.

\section{Hasil}

\section{Tabel 1}

Perbandingan Nilai kecenderungan perilaku bullying pada kelompok kontrol dan kelompok intervensi saat pre-test dan post-test pada siswa SMPN 1 Rajeg Kabupaten Tangerang Tahun 2016

\begin{tabular}{lcc}
\hline & Pre Intervensi & Post Intervensi \\
\hline Intervensi & & \\
Mean & 45,80 & 40,71 \\
SD & 6,512 & 6,783 \\
Minimal & 30 & 20 \\
Maksimal & 58 & 53 \\
& & \\
Kontrol & & 43,02 \\
Mean & 42,85 & 4,932 \\
SD & 5,318 & 30 \\
Minimal & 33 & 59 \\
Maksimal & 58 & \\
& & \\
\hline
\end{tabular}

Tabel 1. menunjukkan bahwa nilai rerata kecenderungan perilaku bullying pada kelompok intervensi sebelum dilakukan terapi asertif adalah 45,8, sedangkan setelah dilakukan terapi asertif nilai rerata menjadi 40,71, sedangkan pada kelompok control sebelum adalah 42,85 sedangkan setelah 43,02. Hasil ini memperlihatkan ada penurunan tingkat kecenderungan perilaku bullying pada kelompok intervensi setelah dilakukan terapi asertif, sedangkan pada kelompok control terjadi peningkatan sedikit kecenderungan perilaku bullying. Kecenderungan perilaku bullying pada kedua kelompok masih dalam taraf sedang, artinya belum masuk tahap kecenderungan perilaku bullying berat. Tahap sedang hanya seputar bullying yang sifatnya verbal, belum mengarah pada tindakan kekerasan.

\section{Diagram 4.1}

Diagram Distribusi Rerata Frekuensi kecenderungan perilaku bullying pada Kelompok Intervensi dan Kontrol Sebelum dan Setelah dilakukan intervensi

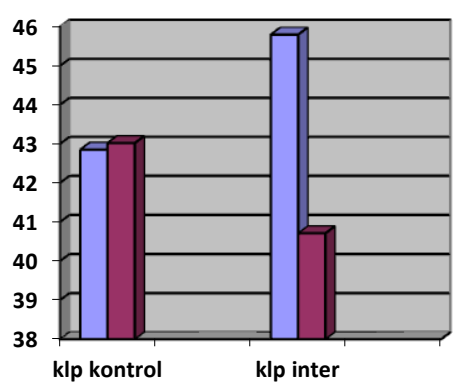

\section{Perbandingan rerata selisih} kecenderungan perilaku bullying sebelum dan setelah terapi asertif pada kelompok Intervensi dan kelompok kontrol. 
Perbandingan rerata angak kejadian PMS diidentifikasi sebagai selisih nilai pre-tes dan post-test ada masing-masing kelompok.

\section{Tabel 2}

Perbandingan rata-rata selisih kecenderungan perilaku bullying pada kelompok intervensi dan kelompok kontrol siswa SMPN 1 Rajeg Kabupaten Tangerang 2016

\begin{tabular}{llllll}
\hline Variabel & Klp & Mean & SD & Df & $\begin{array}{l}\mathrm{p} \\
\text { value }\end{array}$ \\
\hline Kejadian & Intervensi & & & & \\
PMS & Sebelum & 45,80 & 6,512 & 40 & 0,000 \\
& Setelah & 40,71 & 6,783 & & \\
& Perbedaan & 5,098 & 5,286 & & \\
& & & & & \\
& Kontrol & & & & \\
& Sebelum & 42,85 & 5,318 & 42 & 0,744 \\
& Setelah & 43,02 & 4,932 & & \\
& Perbedaan & - & 3,429 & & \\
& & 0,186 & & & \\
\hline
\end{tabular}

Tabel.2 menunjukkan rata-rata

kecenderungan perilaku bullying pada siswa SMPN 1 Rajeg Kabupaten Tangerang sebelum dilakukan terapi asertif pada kelompok intervensi adalah 45,80 dengan standar deviasi 6,512 dan setelah dilakukan Terapi asertif adalah 40,71 dengan standar deviasi 6,783. Analisa lebih lanjut adanya perbedaan bermakna antara kecenderungan perilaku bullying pada siswa SMP pada kelompok intervensi sebelum dan sesudah dilakukan terapi asertif dengan kata lain ada perbedaan signifikan bahwa terapi asertif dapat menurunkan rata-rata kecenderungan perilaku bullying pada siswa SMP kelompok intervensi sebesar 5,098 (p value $=0,000 \alpha=0,05)$.

\section{Perbedaan Kecenderungan Perilaku Bul- lying Sesudah Intervensi antara ke- lompok kontrol dan Intervensi}

Tabel 3

Perbandingan Rerata Angka Kejadian PMS pada Mahasiswi Antara Kelompok Intervensi dan Kelompok kontrol setelah dilakukan intervensi di Jurusan keperawatan Tangerang Tahun 2015

\begin{tabular}{llllll}
\multicolumn{5}{c}{ keperawatan Tangerang Tahun } & 2015 \\
\hline Variabel & Mean & SD & SE & df & $\begin{array}{l}\mathrm{p} \\
\text { value }\end{array}$ \\
& & & & &
\end{tabular}

Kejadian

PMS

$\begin{array}{llllll}\text { Intervensi } & 5,10 & 5,286 & 0,826 & 40 & 0,000 \\ \text { Kontrol } & -0,186 & 3,075 & 0,565 & 42 & \end{array}$

Tabel 3. menunjukkan rerata penurunan kecenderungan perilaku bullying pada kelompok intervensi adalah 5,10 dengan standar deviasi 5,286 sedangkan pada kelompok kontrol adalah -0,186 dengan standar deviasi 3,705. Hasil analisis lebih lanjut didapatkan bahwa ada perbedaan selisih rerata antara kelompok intervensi dan kelompok control dan setelah di uji perbedaan tersebut signifikan ( $p$ value $=0.000$, $\alpha=0,05)$.

\section{Pembahasan}

Perbandingan rerata kecenderungan perilaku bullying pada kelompok intervensi dan kelompok kontrol sebelum dan seudah dilakukan terapi asertif pada kelompok intervensi

Kecenderungan perilaku bullying sebelum dan sesudah terapi asertif pada siswa SMP pada kelompok intervensi, menunjukkan ada penurunan kecender- 
ungan perilaku bullying pada kelompok intervensi. Hal ini dilihat dari nilai rerata pada kelompok intervensi sebelum dilakukan terapi asertif yaitu 45,80 dan setelah dilakukan terapi asertif nilai rerata kelompok ini adalah 40, 71 . Analisa lebih lanjut adanya perbedaan bermakna antara kecenderungan perilaku bullying pada siswa SMP pada kelompok intervensi sebelum dan sesudah dilakukan terapi asertif dengan kata lain ada perbedaan signifikan bahwa terapi asertif dapat menurunkan rata-rata kecenderungan perilaku bullying pada siswa SMP kelompok intervensi sebesar 5,098 (p value $=0,000 \alpha=0,05$ ).

Terapi aserti yang diberikan pada kelompok intervensi terdiri dari 4 sesi, dimana tahapan pertama adalah menjelaskan tentang definisi, tujuan dan manfat perilaku asetif yang harus dipunyai oleh setiap individu. Sesi berikutnya adalah melakukan diskusi terkait perilaku asertif yang telah dilakukan oleh siswa, kemudian berlatih terapi asertif yang dilakukan dalam kehidupan seharihari.

Beberapa siswa dibentuk dalam kelompok dimana setiap kelompok melakukan roleplay, bagaimana perilaku asertif dan tidak asertif yang pernah dialami. Dalam sesi roleplay beberapa perilaku aserti dicontohkan oleh siswa seperti budaya mengantri, menghargai hasil karya teman, tidak mencontek dan meminta dengan baik-baik keinginan yang disampaikan dengan car tidak memaksa.

Sesi selanjutnya adalah mengevaluasi hasil dari roleplay dan terapis memberikan penguatan secara positif perilaku asertif yang sudah baik yang dilakukan oleh siswa.Latihan terapi asertif ini ternyata secara signifikan merubah kecenderungan perilaku bullying yang ditunjukkan oleh kelompok intervensi, karena dalam latihan asertif merupakan penerapan latihan tingkah laku dengan sasaran membantu individuindividu dalam mengembangkan cara-cara berhubungan yang lebih langsung dalam situasi-situasi interpersonal. Fokusnya adalah mempraktekkan melalui permainan peran, kecakapan-kecakapan bergaul yang baru diperolah sehingga individu-individu diharapkan mampu mengatasi ketakmemadaiannya dan belajar mengungkapkan perasaan-perasaan dan pikiran-pikiran mereka secara lebih terbuka disertai keyakinan bahwa mereka berhak untuk menunjukkan reaksi-reaksi yang terbuka itu. (Willis, 2004).

Perubahan kecenderungan perilaku bullying sesuai dengan teori perubahan sikap yang dikemukakan oleh Azwar 2005, bahwa hal ini dimungkinkan karena pada teori perubahan sikap yaitu sikap seseorang dipengaruhi oleh pengalaman pribadi, budaya dan lingkungan serta orang yang dianggap penting. 
Pada sesi latihan terapi asertif memberikan pengalaman pada siswa dampak positif yang dapat dirasakan setelah melakukan perilaku asertif yaitu dapat menghargai diri sendiri dan orang lain.

Latihan asertif dilakukan bersama dengan teman sebaya di kelompoknya sehingga memberikan dampak yang positif bahwa perubahan sikap yang baik, yaitu ada penurunan kecenderungan perilaku bullying. Latihan asertif ini dikembangkan bersamasama di lingkungan sendiri sehingga dapat menjadi kebiasaan yang baik.

Pengaruh sikap juga bisa dipenaruhi oleh orang disekitar yang dianggap penting. Pada saat sesi latihan asertif, terapis bersama asisten peneliti mencontohkan bagaimana sikap asertif yang baik dalam kehidupan sehari-hari sehingga ini menjadi factor perubahan sikap karena latihan asertif ini juga dicontohkan oleh terapis bersama dengan asisten peneliti sehingga memberikan contoh yang baik dari orang yang dianggap penting.

\section{Analisis Perbandingan rerata kecender- ungan perilaku bullying antara kelompok intervensi dan kelompok kontrol setelah diberikan Intervensi pada kelompok Intervensi.}

Penelitian ini menggunakan dua kelompok. Kelompok yang pertama adalah kelompok intervensi yaitu keolompok yang diberikan latihan terapi aserti. Sedangkan kelompok yang kedua adalah kelompok control yang tidak diberikan terapi asertif. Hasil penelitian menunjukkan bahwa rerata penurunan kecenderungan perilaku bullying pada kelompok intervensi adalah 5,10 dengan standar deviasi 5,286 sedangkan pada kelompok kontrol adalah -0,19 dengan standar deviasi 3,705. Hasil analisis lebih lanjut didapatkan bahwa ada perbedaan selisih rerata antara kelompok intervensi dan kelompok control tetapi setelah di uji perbedaan tersebut signifikan ( $\mathrm{p}$ value $=0.000$, $\alpha=0,05)$.

Hasil penelitian ini sesuai dengan penelitian yang dilakukan oleh K. Khamida tahun 2013 yang melakukan terapi kelompok suportif pada pasien perilaku kekerasan. Penelitian ini bertujuan menganalisa pengaruh terapi kelompok suportif asertif terhadap perilaku kekerasan pada pasien skizofrenia berdasarkan model keperawatan interaksi King. Desain penelitian ini pre-post test control group desain. Populasi penelitian adalah pasien dengan masalah perilaku kekerasan di ruang rawat inap RS Jiwa Menur Surabaya. Besar sampel 20 responden diambil secara simple random. Variabel bebas adalah terapi kelompok suportif asertif dan variabel tergantungnya perilaku kekerasan. Data dikumpulkan dengan mengisi lembar observasi.

Hasil penelitian menunjukkan bahwa sebelum diberikan terapi kelompok suportif asertif, rerata nilai perilaku kekerasan kelompok perlakuan adalah 96,1, sedangkan pada kelompok 2 kontrol adalah 75,1. 
Setelah diberikan terapi kelompok suportif asertif, rerata nilai perilaku kekerasan kelompok perlakuan adalah 58,4, sedangkan kelompok kontrol 54,8. Hasil uji didapatkan pada kelompok perlakuan ada perbedaan nilai perilaku kekerasan sebelum dan sesudah diberikan terapi kelompok suportif asertif $(p=0,005)$, dan pada kelompok kontrol ada perbedaan antara nilai perilaku kekerasan sebelum dan sesudah diberikan terapi $(p=0,000)$, serta ada pengaruh pemberian terapi kelompok suportif asertif terhadap perilaku kekerasan $(\mathrm{p}=0,045)$. Terapi kelompok suportif asertif berdasarkan model keperawatan Interaksi King dapat menurunkan perilaku kekerasan pasien dengan cara mengoptimalkan system personal dan secara interpersonal saling memberikan dukungan dalam kelompok. Untuk itu diperlukan penelitian kualitatif untuk melengkapai informasi tentang sejauh man terapi kelompok supotif asertif berpengaruh menurunkan perilaku kekerasan.

Terapi asertif menurut Willis (2004) terapi behavioral berasal dari dua arah konsep yakni Pavlovian dari Ivan Pavlov dan Skinerian dari B.F Skinner. Mula-mula terapi ini dikemabangkan oleh Wolpe untuk menanggulangi neurosis. Neurosis dapat dijelaskan dengan mempelajari perilaku yang tidak adaptif melalui proses belajar. Dengan kata lain perilaku yang menyimpang bersumber dari hasil belajar di lingkungan. as- sertive training (latihan asertif) merupakan penerapan latihan tingkah laku dengan sasaran membantu individu-individu dalam mengembangkan cara-cara berhubungan yang lebih langsung dalam situasi-situasi interpersonal. Fokusnya adalah mempraktekkan melalui permainan peran, kecakapankecakapan bergaul yang baru diperolah sehingga individu-individu diharapkan mampu mengatasi ketakmemadaiannya dan belajar mengungkapkan perasaan-perasaan dan pikiran-pikiran mereka secara lebih terbuka disertai keyakinan bahwa mereka berhak untuk menunjukkan reaksi-reaksi yang terbuka itu. Dari latihan-latihan yang diberikan ini dapat mempengaruhi sikap siswa untuk dapat memahami bahwa keterbukaan dalam mengungkapkan perasaan dapat berdampak positif terhadap menurunkan kecenderungan perilaku bullying siswa SMPN 1 Rajeg Kabupaten Tangerang.

\section{Simpulan}

Ada perbedaan yang signifikan selisih rerata antara kelompok intervensi dan kelompok kontrol ( $\mathrm{p}$ value $=0.000, \alpha=0,05$ ), pada kelompok kelompok intervensi terdapat adanya perbedaan yang signifikan, sehingga dapat disimpulkan bahwa terapi asertif berpengaruh terhadap penurunan kecenderungan perilaku bullying. 


\section{Daftar Pustaka}

Coloroso B. The Bully, The Bullied, and The Bystander. New York: Collins Living. 2004.

Hurlock EB. Psikologi Perkembangan. Alih bahasa: Istiwidayati, Soedjarwo. Jakarta: Penerbit Erlangga. 1997: 237.

Khamida.K. Terapi kelompok suportif asertif menurunkan nilai perilaku kekerasan pasien skizofrenia berdasarkan model keperawatan King. journal.unusa.ac.id/index.php/jhs/article/d ownload/33/32

Lange AJ, Jakubowski P. Responsible Assertive Behavior. Illinois: Research Press. 1976: 1-7.

Ninggalih R. Hubungan antara Konsep Diri dengan Perilaku Asertif pada Siswa Korban Bullying di MTs Al-Falah Wujil dan MTs NU Ungaran Kabupaten Semarang. Skripsi Program Sarjana, Fakultas Psikologi, Universitas Diponegoro, Semarang. 2008.

Partosuwido SR. Penyesuaian diri mahasiswa dalam kaitannya dengan konsep diri. Jurnal Psikologi UGM. Yogyakarta: UGM. 1993.

Riauskina II, Djuwita R, Soesetio SR. Gencet-gencetan di mata siswa kelas 1 SMA: Naskah kognitif tentang arti, skenario, dan dampak gencetgencetan. Jurnal Psikologi Sosial 12(1). 2005: 1 - 13.

Rakos RF. Assertive Behavior. New York: Routledge Chapman and Hall Inc. 1991: 170-180.

Sullivan K, Cleary M, Sullivan G. Bullying in Secondary Schools. California: Corwin Press. 2005: 1-21.
Shavelshon RJ, Hubner JJ, Stanton GC. Evaluation of Behavior in Specific Situation. Dalam: Adolescence, Adolescents. Fuhrmann BS (Editor). London: Scott Foresman and Co. 1990: 338.

Taki M. Japanese School Bullying: Iijime. URL: http://www.nier.go.jp/a000110/Toro nto.pdf 